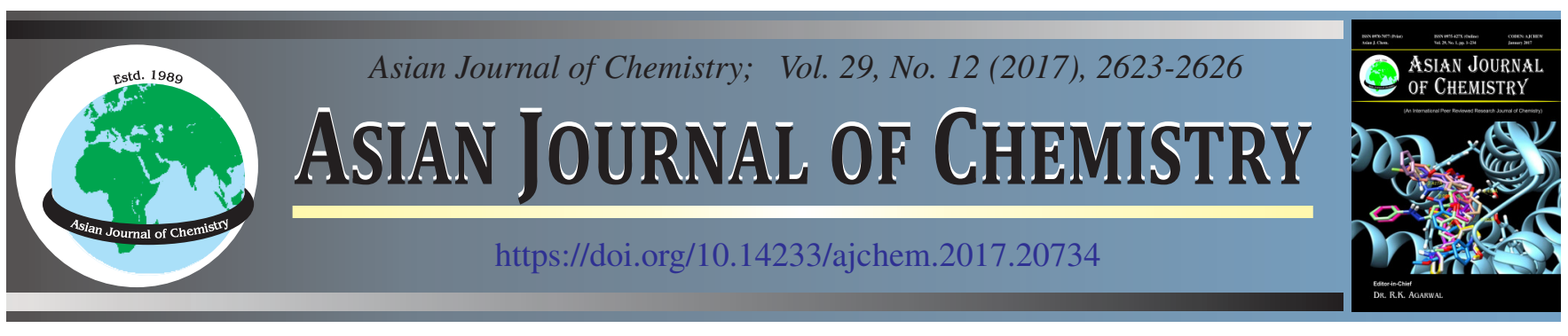

\title{
Development and Validation of Cost Effective UV-Spectrophotometric Method for Estimation of Domperidone in Bulk and Pharmaceutical Formulations
}

\author{
Satish Reddi ${ }^{*}$, Gautam Singhvi, Archana Khosa and Ranendra N. Saha
}

Department of Pharmacy, Birla Institute of Technology and Sciences, Pilani Campus, Pilani-333 031, India

*Corresponding author: E-mail: satish.reddi@pilani.bits-pilani.ac.in; reddi9687@gmail.com

\section{INTRODUCTION}

Domperidone, a benzimidazole derivative, is a peripheral dopamine antagonist with antiemetic and gastroprokinetic properties [1]. Chemically (Fig. 1), it is 6-chloro-3-\{1-[3-(2oxo-3H-benzimidazol-1-yl)propyl]piperidin-4-yl $\}-1 \mathrm{H}-$ benzimidazol-2-one. Its action is similar to metoclopramide hydrochloride but its inability to cross blood-brain barrier attributed to fewer neurological adverse effects than metoclopramide [2]. It thus offers superior safety profile for long-term oral administration in the recommended doses. Domperidone is approved in India, United Kingdom and many other countries and can now be officially prescribed to patients in the United States through an expanded access investigational new drug application for the treatment of gastroesophageal reflux disease with upper gastrointestinal symptoms, gastroparesis, and chronic constipation [3]. Literature survey has revealed that UV-spectroscopic [4-6], HPTLC [7], RP-HPLC [8-10], and LC-MS $[11,12]$ methods are reported for estimation of domperidone. HPLC and LC-MS methods requires sophisticated instrument and complex procedures. Furthermore, these methods are time consuming and costlier. There are few UV-spectroscopic methods are reported but use of organic solvents, complex procedure and need for additional dilution steps for in vitro release study are the major limitations. Thus, there is a need for a simple,<smiles>O=c1[nH]c2ccccc2n1CCCN1CCC(n2c(=O)[nH]c3cc(Cl)ccc32)CC1</smiles>

Fig. 1. Chemical structure of domperidone

rapid and cost effective UV method for routine analysis at industry and research labs. Therefore, the aim of the present study is to develop and validate UV spectrophotometric method for estimation of domperidone in routine analysis which is economic and less time consuming.

\section{EXPERIMENTAL}

Domperidone was obtained as gift sample from Lubrizol Advanced Material Pvt. Ltd., India. Marketed formulation containing $10 \mathrm{mg}$ of domperidone (Domperi DT, IPCA Laboratories Ltd., India) was purchased from local Indian market. All other chemicals and reagents used were of analytical grade 
and purchased from SD Fine-Chem Ltd. and Rankem Pvt. Ltd., India. Ultrapurewater was obtained using Millipore purification assembly (Mill-Q Plus, Millipore, MA, USA).

Spectroscopic measurements were performed a doublebeam UV-Vis-NIR spectrophotometer(Shimadzu Corporation, Japan; model: UV3600) connected to computer loaded with UVProbe software (Version 2.42). For intermediate precision study a double-beam UV-Vis-NIR spectrophotometer (Shimadzu Corporation, Japan; model: UV1800) connected to computer loaded with UVProbe software (Version 2.42) was used. Both the instruments have an automatic wavelength accuracy of $0.1 \mathrm{~nm}$ and matched quartz cells of $10 \mathrm{~mm}$ path length.

Analytical method development: In the preliminary study, various aqueous buffer and solvent were screened to develop a suitable UV-spectrophotometric method for the analysis of domperidone. Media was selected based on solubility of the drug, good sensitivity, ease of sample preparation, economy of the method and its applicability. Drug solutions in the selected media were scanned in the range from 200-400 nm wavelengths for selecting the wavelength of analysis.

Calibration standards: Stock solutions of domperidone with $100 \mu \mathrm{g} \mathrm{mL}^{-1}$ were prepared in selected media by dissolving $10 \mathrm{mg}$ of the drug in $100 \mathrm{~mL}$ of buffer media. Different concentrations were prepared from stock solution by transferring aliquots of stock solutions into a series of $10 \mathrm{~mL}$ standard volumetric flasks and volumes were made with respective media. Six different concentrations were prepared in the range of 5$35 \mu \mathrm{g} \mathrm{mL} \mathrm{m}^{-1}$ of domperidone in selected media for calibration curve development.

Analytical method validation: The developed method was validated in terms of specificity and selectivity, linearity and range, precision, accuracy, limit of detection, limit of quantification, and robustness as per USP and ICH guidelines [13$16]$.

Apparent molar absorptivity and Sandell's sensitivity were calculated according to standard formula. Specificity and selectivity of the proposed method was established by preparing drug solution in selected media along with and without common formulation excipients such as microcrystalline cellulose, dicalcium phosphate, starch, Carbopol 971, etc. All the samples were scanned from $200-400 \mathrm{~nm}$ at speed of $200 \mathrm{~nm} \mathrm{~min}^{-1}$ to observe any change in the absorbance at respective wavelength and spectrum. In a separate study, drug concentration of 20 $\mu \mathrm{g} \mathrm{mL}{ }^{-1}$ was prepared for pure drug and marketed formulation in selected media and analyzed $(\mathrm{N}=5)$. Paired $t$-test at $95 \%$ level of significance was used to compare the means of absorbance.

To establish linearity of the proposed method, nine separate series of solutions of the drug (5-35 $\left.\mu \mathrm{g} \mathrm{mL}^{-1}\right)$ from stock solutions were prepared and analyzed. Least square regression analysis was done for the obtained data. ANOVA test (one-way) was performed based on the absorbance values observed for each drug concentration during the replicate measurement of the standard solutions.

To determine the accuracy of the proposed method, different quality control (QC) levels of drug concentration [lower quality control (LQC), medium quality control (MQC) and higher quality control (HQC)] were prepared from independent stock solution and analyzed.
Accuracy was assessed as the percentage analytical recovery and percentage bias:

$\operatorname{Bias}(\%)=\frac{(\text { Predicted concentration }- \text { Nominal concentration })}{\text { Nominal concentration }} \times 100$

Further, different concentrations of the pure drug were added to a known pre-analyzed formulation sample and analyzed using the proposed method to check the recovery. The percent analytical recovery of the added pure drug was calculated as follows:

$$
\text { Analytical recovery }(\%)=\frac{\left(\mathrm{C}_{\mathrm{T}}-\mathrm{C}_{\mathrm{F}}\right)}{\mathrm{C}_{\mathrm{A}}} \times 100
$$

where $\mathrm{C}_{\mathrm{T}}$ is the total drug concentration measured after standard addition, $\mathrm{C}_{\mathrm{F}}$ is the drug concentration in the formulation sample, $\mathrm{C}_{\mathrm{A}}$ is the drug concentration added to formulation sample.

For precision study of the method, intra-day and interday precision studies were carried out by estimating the responses of three QC standards in triplicates under same experimental conditions three times on the same day and on three different days. From the results obtained, the precision was expressed as percentage relative standard deviations (\% RSD) from mean intra and inter-day assays.

The limit of detection (LOD) is defined as the lowest detectable concentration and limit of quantification (LOQ) is defined as lowest quantifiable concentration. LOD and LOQ were calculated as $3.3 \mathrm{\sigma} / \mathrm{s}$ and $10 \sigma / \mathrm{s}$, respectively, where ' $\sigma$ ' is standard deviation (SD) of intercept and 's' is slope of calibration curve.

To determine the robustness of developed method, QC concentrations were evaluated in media with change in $\mathrm{pH}$ by \pm 0.2 unit and calculated the mean $\%$ recovery. The stability of domperidone in solvent medium was evaluated using QC samples at room temperature. Quality control samples were analyzed at 12, 24 and $48 \mathrm{~h}$ intervals at room temperature using developed method.

The proposed validated UV method was successfully applied for the estimation of total drug content in commerical formulation of domperidone (Domperi DT $10 \mathrm{mg}$ tablets) and in-house developed pellets containing $30 \mathrm{mg}$ of domperidone.

\section{RESULTS AND DISCUSSION}

Optimization of media: The composition and $\mathrm{pH}$ of aqueous media decided was $100 \mathrm{mM}$ hydrochloric acid buffer (pH 1.2) based on drug solubility, sensitivity of method, cost, ease of preparation and applicability of method to dissolution studies. The $\lambda_{\max }$ of domperidone was found to be $284 \mathrm{~nm}$ with maximum absorbance.

Calibration curve: Six different concentrations were prepared in the range of $5-35 \mu \mathrm{g} \mathrm{mL}^{-1}$ of domperidone in the $100 \mathrm{mM} \mathrm{HCl}$ medium for calibration curve development. The calibration data are presented in Table-1.The linear regression equation obtained was (at $284 \mathrm{~nm}$ for $100 \mathrm{mM} \mathrm{HCl}$ ): absorbance $=0.0289 x$ concentration $\left(\mu \mathrm{g} \mathrm{mL}^{-1}\right)+0.0077$ with regression coefficient of 0.9999 . At all the concentration levels, the SD was low and the \% RSD did not exceed 1.30. Apparent molar absorptivity and Sandell's sensitivity of drug was found to be $1.27 \times 10^{4} \mathrm{~L} \mathrm{~mol}^{-1} \mathrm{~cm}^{-1}$ and $0.034336 \mu \mathrm{g} \mathrm{cm}^{-2} / 0.001 \mathrm{~A}$, respectively. 


\begin{tabular}{ccc}
\hline \multicolumn{3}{c}{ TABLE-1 } \\
CALIBRATION CURVE DATA OF THE DEVELOPED \\
METHODS (EACH VALUE IS RESULT OF NINE \\
SEPARATE DETERMINATIONS) \\
\hline $\begin{array}{c}\text { Drug concentration } \\
\left(\mu \mathrm{g} \mathrm{mL}^{-1}\right)\end{array}$ & $\begin{array}{c}\text { Absorbance at } \\
284 \mathrm{~nm} \pm \mathrm{SD}^{\mathrm{a}}\end{array}$ & $\mathrm{RSD}^{\mathrm{b}}(\%)$ \\
\hline 5 & $0.1518 \pm 0.002$ & 1.295 \\
10 & $0.2976 \pm 0.001$ & 0.238 \\
15 & $0.4418 \pm 0.002$ & 0.477 \\
20 & $0.5858 \pm 0.003$ & 0.541 \\
25 & $0.7309 \pm 0.009$ & 1.199 \\
35 & $1.0200 \pm 0.009$ & 0.829 \\
\hline${ }^{\mathrm{a}}$ Standard deviation; ${ }^{\mathrm{b}}$ Relative standard deviation
\end{tabular}

Validation of analytical method: The summary of various optical characteristics, statistical data of the regression equations and validation parameters are shown in Table-2. In the selectivity investigation, the UV absorption spectrum of domperidone was not changed in the presence of common formulation excipients as shown in Fig. 2. There was no difference in absorbance values or spectra of drug solutions prepared from pure drug and in presence of excipients. The calculated $t$-values were found to be less than that of the critical $t$-value, which indicates that statistically there was no significant difference between

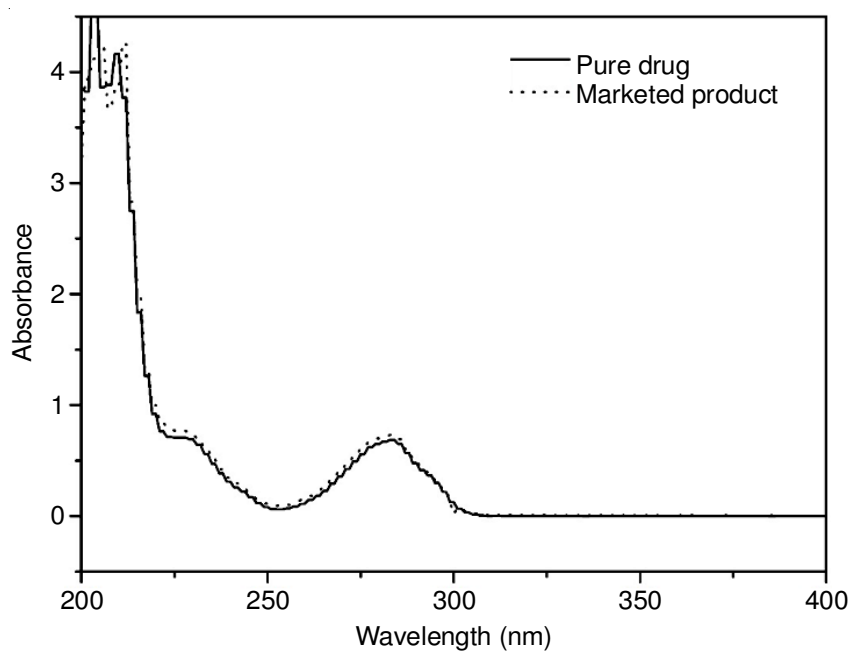

Fig. 2. UV absorption spectra of domperidone in bulk form and marketed formulations (Solid line - pure drug; Dotted line - drug in marketed formulations)

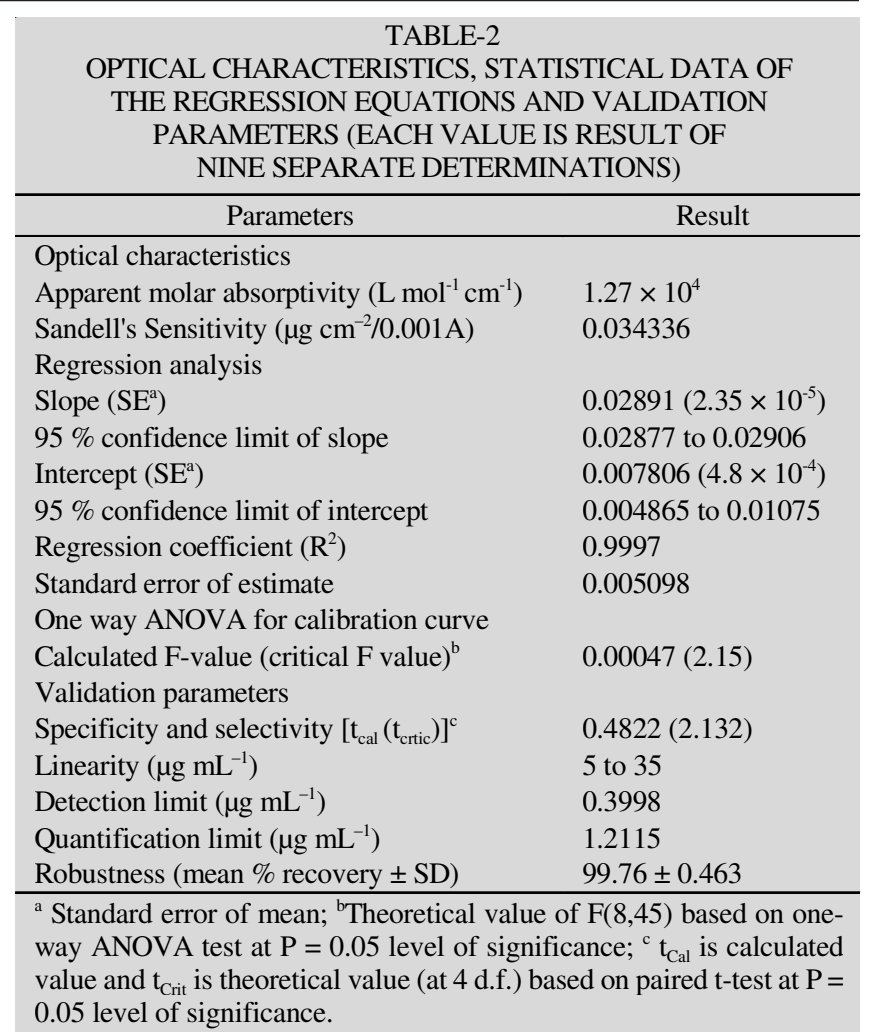

mean absorbance of domperidone solutions prepared from pure drug and marketed tablet formulation (Table-2). Therefore, the proposed method is specific and selective for domperidone.

The linearity range was found to be $5-35 \mu \mathrm{g} \mathrm{mL}^{-1}$ in the selected medium at $284 \mathrm{~nm}$. Lower values of parameters like standard error of slope and intercept (Table-2) indicated high precision of the proposed method. High regression coefficient values and less calculated F-values demonstrates the goodness of fit of regression equations.

The developed method showed high and consistent absolute recoveries at all studied QC levels. All the quality control levels $\left(\mathrm{LQC}=7 \mu \mathrm{g} \mathrm{mL} \mathrm{g}^{-1}, \mathrm{MQC}=17 \mu \mathrm{g} \mathrm{mL}^{-1}\right.$ and $\mathrm{HQC}=27 \mu \mathrm{g} \mathrm{mL}^{-1}$ ) showed an accuracy (\% Bias) ranging from -0.12 to 0.77 in hydrochloric acid buffer medium (Table-3). Further, the accuracy was validated by performance recovery studies of standard addition method (Table-4). The mean recoveries (\% RSD) for

\begin{tabular}{|c|c|c|c|c|c|}
\hline \multirow{3}{*}{ Level } & \multicolumn{4}{|c|}{$\begin{array}{l}\text { TABLE-3 } \\
\text { RESULTS OF ACCURACY STUDIES BY PERCENTAGE RECOVERY METHOD } \\
\text { (EACH VALUE IS RESULT OF NINE SEPARATE DETERMINATIONS) }\end{array}$} & \multirow{3}{*}{$\begin{array}{l}\text { Accuracy } \\
(\%)\end{array}$} \\
\hline & \multicolumn{3}{|c|}{ Predicted concentration $\left(\mu \mathrm{g} \mathrm{mL^{-1 } )}\right.$} & \multirow{2}{*}{$\begin{array}{c}\text { Mean } \% \\
\text { recovery } \pm \text { SD }\end{array}$} & \\
\hline & Range & Mean \pm SD & $\operatorname{RSD}(\%)$ & & \\
\hline LQC & $6.93-7.07$ & $6.99 \pm 0.057$ & 0.821 & $100.11 \pm 1.103$ & -0.165 \\
\hline MQC & $16.97-17.24$ & $17.13 \pm 0.083$ & 0.482 & $100.09 \pm 0.791$ & 0.769 \\
\hline HQC & $26.72-27.10$ & $26.97 \pm 0.150$ & 0.557 & $100.05 \pm 0.889$ & -0.114 \\
\hline
\end{tabular}

TABLE-4

RESULTS OF ACCURACY STUDIES BY STANDARD ADDITION METHOD

(EACH VALUE IS RESULT OF THREE SEPARATE DETERMINATIONS)

\begin{tabular}{cccc}
\hline $\begin{array}{c}\text { Drug in formulation } \\
\left(\mu \mathrm{g} \mathrm{mL}^{-1}\right)\end{array}$ & $\begin{array}{c}\text { Pure drug added } \\
\left(\mu \mathrm{gL} \mathrm{m}^{-1}\right)\end{array}$ & $\begin{array}{c}\text { Actual total concentration } \\
\text { of drug }\left(\mu \mathrm{mL}^{-1}\right)\end{array}$ & $\begin{array}{c}\text { Mean predicted } \\
\text { concentrations }\left(\mu \mathrm{g} \mathrm{mL}^{-1}\right)\end{array}$ \\
\hline 10 & 5 & 15 & 14.96 \\
10 & 10 & 20 & 20.01 \\
10 & 15 & 25 & 25.04 \\
\hline
\end{tabular}


TABLE-5

RESULTS OF INTERMEDIATE PRECISION STUDY

\begin{tabular}{ccccc}
\hline $\begin{array}{c}\text { Concentration } \\
\left(\mu \mathrm{g} \mathrm{mL}^{-1}\right)\end{array}$ & \multicolumn{2}{c}{ Intra-day repeatability RSD $(\%)(\mathrm{n}=9)$} & \multicolumn{2}{c}{$\begin{array}{c}\text { Inter-day repeatability } \\
\text { RSD }(\%)(\mathrm{n}=27)\end{array}$} \\
\cline { 2 - 4 } LQC & Day 1 & Day 2 & Day 3 & 0.873 \\
MQC & 0.791 & 1.176 & 1.396 & 0.544 \\
HQC & 0.475 & 0.565 & 0.463 & 0.661 \\
RSD $(\%)(\mathrm{n}=6)$
\end{tabular}

LQC, MQC and HQC were found to be 100.11 (1.10), 100.09 $(0.79)$ and $100.05(0.89)$, respectively. The result shows that the proposed method can accurately measure any small change in the drug concentration in solution.

Precision of the proposed method was studied by evaluating repeatability and intermediate precision. The \% RSD of interday and intraday precision was found to be not more than 1.39 at all three QC levels of concentrations as shown in Table-5. Low \% RSD values indicated the excellent precision of proposed method.

The LOD and LOQ were found to be $0.39 \mu \mathrm{g} \mathrm{mL}^{-1}$ and $1.21 \mu \mathrm{g} \mathrm{mL}^{-1}$, respectively which indicate the excellent sensitivity in UV spectroscopic method. Variation of $\mathrm{pH}( \pm 0.2)$ did not have any significant effect on the UV absorbance of domperidone, which confirm the robustness of the proposed method (Table-2).

Stability of the drug in solvent medium was investigated and mean recovery after $48 \mathrm{~h}$ was found within limits. Results compiled in Table- 6 confirmed that domperidone is stable in selected solvent media for sufficient time.

\section{TABLE-6}

STABILITY STUDIES OF QC SAMPLES AFTER $48 \mathrm{~h}$ (EACH VALUE IS RESULT OF FIVE SEPARATE DETERMINATION)

\begin{tabular}{ccc}
\hline $\begin{array}{c}\text { Concentration } \\
\left(\mu \mathrm{g} \mathrm{mL}^{-1}\right)\end{array}$ & $\begin{array}{c}\text { Predicted } \\
\text { concentration } \pm \mathrm{SD}\end{array}$ & $\begin{array}{c}\text { Mean }(\%) \\
\text { recovery } \pm \mathrm{SD}\end{array}$ \\
\hline $\mathrm{LQC}$ & $6.94 \pm 0.072$ & $99.18 \pm 1.029$ \\
$\mathrm{MQC}$ & $17.12 \pm 0.105$ & $100.74 \pm 0.621$ \\
$\mathrm{HQC}$ & $26.95 \pm 0.111$ & $99.82 \pm 0.411$ \\
\hline
\end{tabular}

The assay values of domperidone for different formulations ranged from 99.84 to $100.22 \%$ with SD not more than 1.10 (Table-7). Assay values of formulations were found to be very close to the labeled claim, suggesting that the interference of excipient matrix was insignificant in the estimation of domperidone by proposed method. The estimated drug content with low values of SD establishes the precision and applicability of the proposed method.

TABLE-7

APPLICATION OF THE PROPOSED SPECTROPHOTOMETRIC METHODS TO THE DETERMINATION OF DOMPERIDONE IN DOSAGE FORMS (EACH VALUE IS RESULT OF SIX SEPARATE DETERMINATIONS)

\begin{tabular}{ccc}
\hline Formulations & $\begin{array}{c}\text { Amount } \\
\text { found } \pm \text { SD }\end{array}$ & Assay $(\%) \pm$ SD \\
\hline $\begin{array}{c}\text { Marketed formulation: } \\
\text { Domperi DT 10 mg tablets } \\
\text { In-house pellets containing 30 } \\
\text { mg of domperidone }\end{array}$ & $10.02 \pm 0.05$ & $100.22 \pm 0.565$ \\
\hline
\end{tabular}

\section{Conclusion}

The proposed UV spectrophotometric method is simple, rapid, accurate, precise and economical for the UV estimation of domperidone in bulk, dosage form and dissolution samples. The proposed method does not require any pretreatment of drug and tedious extraction procedure and sample preparation is not time consuming. The method has wider linear range with good accuracy and precision. Thus, it can be extended for routine analysis of domperidone in pharmaceutical industries and research laboratories.

\section{ACKNOWLEDGEMENTS}

The authors are thankful to Lubrizol Advanced Material Private Limited, Mumbai, India for providing financial support for this project.

\section{REFERENCES}

1. R.D. Allan and G.A.R. Johnston, Clin. Res. Rev., 3, 91 (1983); https://doi.org/10.1002/med.2610030202.

2. R.N. Brogden, A.A. Carmine, R.C. Heel, T.M. Speight and G.S. Avery, Drugs, 24, 360 (1982); https://doi.org/10.2165/00003495-198224050-00002.

3. P.R. Kumar, P.B. Prakash, M.M. Krishna, M.S. Yadav and C.A. Deepthi, E-J. Chem., 3, 142 (2006); https://doi.org/10.1155/2006/640731.

4. A.H. Patel, J.K. Patel, K.N. Patel, G.C. Rajput and N.B. Rajgor, Int. J. Biol. Pharm. Res., 1, 1 (2010).

5. A. Shirwaikar, A. Shirwaikar, C.D. Kumar, A. Joseph, R. Kumar and S.L. Prabu, Indian J. Pharm. Sci., 70, 128 (2008); https://doi.org/10.4103/0250-474X.40351.

6. S.C. Reddymasu, I. Soykan and R.W. McCallum, Am. J. Gastroenterol., 102, 2036 (2007); https://doi.org/10.1111/j.1572-0241.2007.01255.x.

7. B.H. Patel, B.N. Suhagia, M.M. Patel and J.R. Patel, J. Chromatogr. Sci., 46, 304 (2008); https://doi.org/10.1093/chromsci/46.4.304.

8. K. Karunakaran, G. Navaneethan and K.P. Elango, Trop. J. Pharm. Res., 11, 99 (2012); https://doi.org/10.4314/tjpr.v11i1.13.

9. P.V. Rao, C.K.S. Reddy, M.R. Kumar and D.D. Rao, J. Liq. Chromatogr. Rel. Technol., 35, 2322 (2012).

10. S. Thanikachalam, M. Rajappan and V. Kannappan, Chromatographia, 67, 41 (2008); https://doi.org/10.1365/s10337-007-0452-y.

11. A. Bose, U. Bhaumik, A. Ghosh, B. Chatterjee, U.S. Chakrabarty, A.K. Sarkar and T.K. Pal, Chromatographia, 69, 1233 (2009); https://doi.org/10.1365/s10337-009-1032-0.

12. M.J. Smit, F.C.W. Sutherland, H.K.L. Hundt, K.J. Swart, A.F. Hundt and J. Els, J. Chromatogr. A, 949, 65 (2002); https://doi.org/10.1016/S0021-9673(01)01553-9.

13. USP United States pharmacopoeia, NF 26. United States Pharmacopeia Convention, Asian edition, Rockville, 31, p. 683-687 (2008).

14. ICH, Q2R1 Validation of Analytical Procedures: Text and Methodology; International Conference on Harmonization, Geneva (1996).

15. ICH, Q1A(R2), Stability Testing of New Drug Substances and Products, International conference on Harmonization. Geneva (2003).

16. G. Singhvi, P. Kalantare, H. Dhoot and R.N. Saha, Asian J. Chem., 25, 3682 (2013); https://doi.org/10.14233/ajchem.2013.13716. 